\title{
Project Management of Strategic Communication in Digital Era
}

\author{
Miroslav Mitrović \\ Strategic Research Institute \\ University of Defence \\ Belgrade, Serbia \\ mitrovcmm@gmail.com \\ https://orcid.org/0000-0001-7541-856
}

\author{
Ana Vulić \\ Serbian Armed Forces \\ Ministry of Defence \\ Belgrade, Serbia \\ ana.vulic@vs.rs
}

\begin{abstract}
Strategic communication is one of the expressions of state power and represents an instrument in the political and security achievement of national interests. Contemporary conflicts have a form of hybrid acts in the area of usage of information based on the media and Internet. The main goal of strategic communication is to influence the public opinion changing cultural values and adjustment of the political system through the "reprogramming" of the political culture. Listed offensive activities could strongly effect on national defence and security capabilities, influencing on mind of population. Paper describes conceptual correlation among the strategic concept of communication operationalised in project management with psychological behaviour influence in cyberspace. Paper offers modeling of the project approach to designing of strategic communication in the scope of the contemporary digital era. The paper analyses Internet contents on social networks through aspects of possible influence on behaviour and attitudes of the target public, as an object of strategic communication project management.
\end{abstract}

Keywords - strategic communication, communication management, hybrid warfare, public opinion, public behaviour, Internet social networks.

\section{INTRODUCTION}

Not every information has influence, but influence and power are significantly based on information. Strategic communication is a part of contemporary social activities which is in the growing and development phase. Immaturity of phenomena contributes to its undefined and sometimes unclear understanding [1]. In addition, the dynamic of the development of phenomena contributes to a conclusion that not all communications are strategic, as well as that not all strategic communications are conducted toward positive goals [2]. Contemporary understanding of strategic communication is strongly based on a definition suggested by Hallahan, where strategic communication, in its broadest sense, could be understood as "communicating purposefully to advance (the organization's) mission" and "implies that people will be engaged in deliberate communication practice on behalf of organizations, causes, and social movements" [3].

The term strategic communication is consists of two terms: strategy and communication. The use of the concept of strategies in the description of the derivative means that the activity is not accidental or unintentional. Namely, 'strategic' describe that action is in solid correlation with the essential mission of the organisation. On the other hand, the meaning of 'communication' can be observed from aspects of various social sciences such as psychology, sociology or their disciplines, such as social psychology and communications. In colloquial sense, different types of communication expression are used in description of different forms of strategic communication: communication management, integrated communication, reputation management, corporate communications, etc. The essence of strategic communication is an influence on attitudes, information management, persuasion, discursive, and relational communications, used with the purpose, and in the context of achieving and supporting the fulfilment of the mission of the organisation. In short, strategic communication is the term used to indicate the highest level of engagement of the organisation's communication achievements in improving its mission [4].

Strategic communication is a modern management concept of constant adjustment of multidisciplinary interactive communication between different levels and the organisational forms of human society, to achieve targeted relationships and establish links between subjects in the process [5]. In addition, the management of strategic communications implies the way in which the organisation presents itself in society as a social actor, through creating a public culture and in considering issues of public importance. In that sense, strategic communication can be observed on:

- National (state) institutional level: public diplomacy, psychological operations, public affairs, propaganda, interest communication (lobbying, representation of interests, strategic negotiation).

- Corporate level: public relations, integrated marketing communication, socially responsible practices, corporate political activities [6].

In the context of national defence and security ${ }^{1}$, strategic communication can be identified with every

\footnotetext{
1 As a "father" of a coin that reflects the complex and courageous communication processes, channels and instruments engaged in the achievement of goals of national importance in the field of defense
} 
activity, statement, message, description, and action of armed forces that affect the perception and opinion of the population that is the witness, both in the area where the operations are carried out (directly) and in the widest world (indirectly) [8].

At the national level, in order to be successful, strategic communication must include communication content and emission of activities, "images" and politics [9]. It represents coordinated activities, messages, images and other forms of presentation or engagement that intend to inform, influence, or convince the audience in accordance with national objectives [10]. From aspects of state, strategic communication is also an instrument used by governments for rebel operations or armed conflicts to influence the perceptions, attitudes, beliefs and behaviour of subjects in society and beyond, nongovernmental groups, neutral elements, opponents and advisers and allies in the function of supporting the national security policy [11].

Strategic communication aims to understand and engage key stakeholders in the creation, empowerment or preservation of conditions favouring the progress of realizing national interests, policies and objectives with coordinated programs, plans, themes, messages and products synchronised in a zone of possible conflict with the activities of all other national instruments be able to. The concept of strategic communication, along with diplomacy, information, the armed forces, and the economy, should be seen as an instrument of national power [12].

According to the conclusions of the US Military Science Group's working group, strategic communication is an interactive process and a coherent set of activities that include:

- Understanding of identity, approach, behaviour, and culture; trends in the media and the flow of information; social and other influential networks; political, social, economic and religious motivation.

- Advising decision-makers, diplomats and military leaders in relation to the public opinion and its implications regarding policy choices.

- Engagement in dialogue about ideas between an individual and institutions through programs that support national interests.

- Impact on attitudes and behaviour through communication strategies supported a wide range of state and civil society activities.

- Measurement and monitoring of the impact of communication activities [13].

and security, is recognized Vito Vincent, head of the US Department of Defense's Special Department for Defense Studies, is considered to be the "strategic communication" within the framework of the report on the dissemination of information management, 2001 [7].
It can be said that strategic communications have emerged as a national, national concept of influencing international relations as part of the military strategy [14].

\section{STRATEGIC COMMUNICATION PROJECT MANAGEMENT}

Communication is not purposed for itself, but it aims to establish certain relationships between the subjects of the communication process. Relationships are based on the interpretation and definition of messages. Therefore, communication does not occur without meaning, but with the purpose of interpatient of a particular event, phenomenon or value, in order to achieve the desired effect on public opinion, which is the object of the operation of the communication operation. The meaning has a psychological, sociological, cultural dimension, the message is understood and remembered in a particular context, determined by meaning, or establishes ambiguity and indecision, and defines whether and how this consecration is resolved and neutralised [15]. In addition, in designing strategic communication, it is necessary to take into account the denotation and connotation of the meaning of the message, in relation to the specificity of the environment in which the message is placed [16]. Understanding the message depends on a number of factors, such as cultures, religions, customs, traditions, value systems, the degree of the general development of society, level of education, etc.

In the planning of strategic communication, it is necessary to analyse factors that influence the planning and implementation of a certain environment:

- Analysing the factors of the communication environment and objective and subjective forces and weaknesses.

- Strategic planning of the communication process.

- Defining, selecting and planning relevant communication strategies.

- Implementing the communication strategy itself.

- Control of the results of the implementation of individual phases of the communication strategy, it is auditing and finishing.

A functional structure for a designing project for strategic communication is presented in Fig. 1 .

In analogy to the planning of any other strategy, communication strategy, are customised on key process elements:

- Determining the objectives of the communication process.

- Evaluation of the mutual compatibility of the broader communication objective from the aspect of the long-term general strategy, the general values, the following goals with the concrete communication strategy. 
- Estimated total and allocated resources for the implementation of the strategy, as well as their spatial and temporal availability. Analysis of possible crisis moments regarding the availability of resources and planning a response to the crisis.

- Choice of adequate tactics for implementation of communication strategy. Then, create communication tools.

- $\quad$ Timing of tactics, determination of control and corrective points and actions, planning a crisis scenario for each stage of strategy implementation.

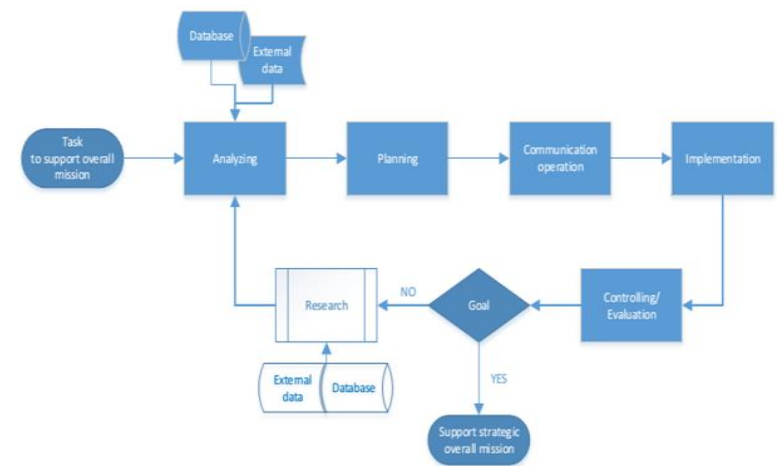

Fig.1. Example of the structure of strategic communication project designing.

From the foregoing, we can conclude that strategic communication is a planned and comprehensive activity of the organisational entity, which aims at achieving a successful and efficient interaction with the environment [17]. In the area of defence and security, strategic communication management (SCM) is carried out with the aim to support the highest national goals particularly trough propaganda, public diplomacy and interest communications [18]. All listed strategic pillows are present in Cyberspace and use Internet as base of communication.

\section{A. Contemporary SCM in the digital era}

Actual strategic communication in the role of support national security issue could be located in several niches, which are in a relation of the postmodern concept of modern warfare [19] recognised as hybrid warfare [20] [21]. Strategic communication, in essence, is orientated at information usage, security, protection, prevention of its abuse in a real and virtual environment, electronically, database and cyberspace. In contests of national security and defence, we could argue about information warfare. Regarding Libicki [22], Information warfare is compound of (1) Command and Control Warfare - $(\mathrm{C} 2 \mathrm{~W})$, (2) Intelligence warfare, (3) Electronically warfare, (4) Psychological warfare, (5) Hacker warfare, (6) Economy intelligence warfare and (7) Cyberwarfare.

In the overall conclusion perspective, we could recognize the projection of an operational approach in the following forms:
- Information operations - The most important determinants that determine the specifics of the conflict in the information sphere are its asymmetry, which enables the opening of unprotected sites in the hostile information system and their attack; concealing the application and the ability to "adapt" subversive information content to the existing information systems of the enemy; flexibility and flexibility in solving the problem of transformation of the information environment [23].

- Cyberwarfare - The cyber-attack carried out by an entity against the state and its society, primarily cyber warfare, is primarily but not solely for the purpose of influencing the behaviour of the targeted party. The attacking actor can be either state or non-state. It is a form of information warfare that consists of a series of actions that interrupt or destroy the information and communication systems of the opponent (e.g. penetration of computer viruses into the opponent's military systems) [24].

Listed aspects are dominantly linked to defence aspects which are incompetence of defence and security system. In favour of task to achieve influence on different target groups of the audience, with the aim of public opinion management and, as a consequence, public behaviour management related to the defence and security issues, we should consider wide society based communication strategy.

In the frame of the article's scope, we consider that the contemporary globalised security environment has hybrid and asymmetry characteristics. Also, developed technical, informational, cyber solutions that are the base for implementation of channels for communication make actual societies dependable on informational and communicational technologies. Moreover, it could be concluded that contemporary civilisation is linked with digitalised communication solutions, which makes all systems (especially defence and security) potentially fragile for all sorts of enlargement of communicational and informational systems, or vulnerable to the attacks in cyberspace [25]. In the context of contemporary strategic communication management, influence considers psychological cognitive stimulus based upon digitalised, Internet social group's platform.

\section{CONTEMPORARY SCM IN THE DIGITAL ENVIRONMENT}

Contemporary psychological operations have become part of information operations. They are described as a set in the whole spectrum of events, planned actions towards the target audience group in a certain area of action, with the goal of acquiring information superiority, designing information space (control over information, information systems, cognitive processes) in accordance with their interests. Psychological operations are planned operations to 
transmit selected information and indicators to a foreign auditorium in order to influence their emotions, motives, objective judgment, and the final behaviour of foreign governments, organisations, groups, and individuals. The purpose of psychological operations is to encourage or strengthen foreign attitudes and behaviours favourable to the objectives of the initiator [26]. Based on Bandurina's socialcognitive theory of personality [27] and Levine's formula [28], according to which personality behaviour is conditioned by the relation of personality and environment in which it is located, functional relation of behaviour (B), personality (P) and environment $(\mathrm{E})$ are presented as:

$$
B=f(P, E)
$$

Influence on personality in cyberspace can affect the predictable behaviour through personality change attitudes, depending on their psychological characteristics and behaviour. The influence on the predictable behaviour of the personality is the goal of contemporary psychological operations that take place in cyberspace. These operations are recognised as "impact operations".

In the information age, the application of information technology in modern psychological operations is widespread and almost unavoidable. The Internet, as the prevailing part of cyberspace, is used as the main medium for the distribution of psychological content. The specialised software tools, present on the Internet, have task to analyse the target groups, with aim for more accurately and efficiently distribution of psychological content. Purpose of this approach is to achieve impacts in a shorter period of time and with as lowest costs.

The Internet is different from other media for three key reasons: 1) the Internet access is unlimited, 'everything' it is 'at your fingertips', 2) the Internet is the medium where the target group actively searches for information, and 3) messages of the impact operations draw attention stronger than any other 'backside' information, including information provided by the opposing party. Therefore, the material of psychological surgery must be extremely attractive and interesting for the target group; that is, it must be adapted to the psychological characteristics of its members.

In modern asymmetric military conflicts, which are prevailed in contemporary hybrid warfare concept, the offensive, attacking side strive to intervene in a state where they want to achieve the political goals of their political and military leaders and commanders. Therefore, they seek to gain the local population for their allies, so that they can carry out the necessary military actions on the ground with their support. In this purpose, psychological operations (PO) shape the behaviour and emotions of people in order to change their attitudes and direct them to act in accordance with the needs of the armed forces. The goal of the PO is to create and disseminate understandable messages that can be read, listened or seen in order to influence the desired behaviour of the target groups. The message can influence the thinking sphere of the target group members, trigger spontaneous emotions, or encourage the reflex behaviour of its members. The effect of PO partly depends on the way on which the message is transmitted to the target group. In order to perform precise psychological operations, what aim to influence on a particular selected specific target group, great importance have information about their behaviour in cyberspace: when, on what way, through which devices and which content is accessed on the Internet. Dynamic of activities and variable fastgrowing changes is illustrated with fallowing NATO suggestion:

“On January 2016, almost half (3.4 billion) of the world's population was actively using the Internet, and $1 / 3$ (or 2.3 billion) of all people were using various social networking sites. Furthermore, the number of mobile social media users is growing by 12 users/second; the mobile phone is now the main way of accessing connected services, including the Internet, for the majority of individuals around the globe. Social media increasingly shapes our perceptions and attitudes as more and more people are turning to social networking sites, such as Twitter and Facebook, to keep up with the news. [29]"

The results of a number of contemporary research have indicated the possibility that personality characteristics determine personality behaviour on the Internet and it is present the basis for the selection of target groups of psychological operations in cyberspace. Therefore, one of the models of actual psychological operations implies influencing the predictable behaviour of a person through the change of beliefs and attitudes, depending on their psychological characteristics and ways of behaviour in cyberspace. The Theory of planned behaviour (TPB), and the "Big Five" model of personality [30] are foundation of this approach.

Concerning Hansen [31] influence on the attitudes and behaviour could be exposed by the following ways: 1) critical resources controlling, 2) fraud and 3) social influence. Social influence by Pratkanis [32] is defined as any non-coercive technique, procedure or manipulation that relies on the socio-psychological nature of human beings as a means of creating or changing the belief or behaviour of the goal. According to Kelman [33], social influence could be manifested in three different ways - (1) harmonisation, (2) identification, and (3) internationalisation. Harmonization is a change in behaviour that usually occurs due to social conformist pressure but without the obligation to change personal beliefs. Identification is a change in behaviour, or attitude, created in the intention of mimicking someone who "likes" and whose outcome is willing to change the beliefs. Internationalisation is the willingness of a person to willingly accept new norms of behaviour, which then leads not only to change in behaviour but also to the change of beliefs that support new norms.

The societal influence on the predictable behaviour of a person through the change of beliefs and attitudes 
can significantly emerge in the cyberspace because the cyberspace has become a global and unavoidable habitat and a hub of the widest personality layer without a religious, national, property, gender, and age limitations.

Social networks and cyberspace have influenced users to change existing behaviour patterns and that "consumers" and passive users of information become their producers and active researchers.

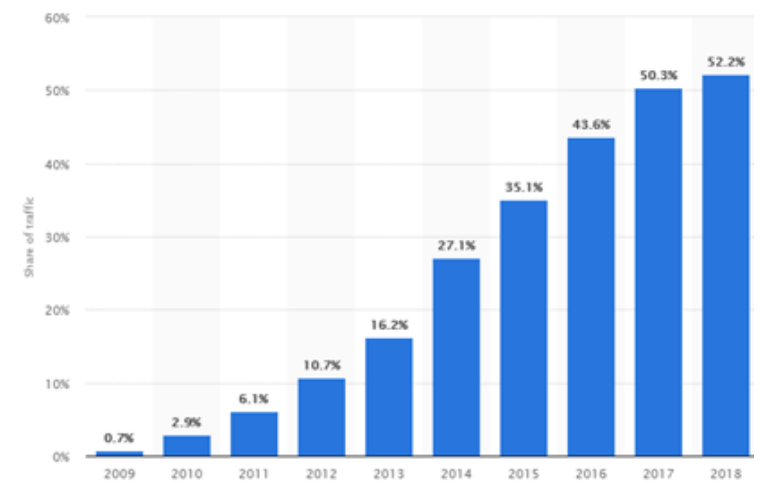

Fig.2. Sum of data which are applicable used on mobile phones platforms in perspective of a percentage of all global web pages served to mobile [34].

The term "cyberspace" has become a conventional means of describing anything connected to the Internet and various Internet cultures. Part of the cyberspace and the most important modern 'Internet cultures' are social networks. Over the past six years, the number of users of these networks has increased more than double ( 0.97 billion in 2010 to more than 2.5 billion in 2017). Due to the low cost of access, the wide variety of users, the global distribution and high speed of information flow, social networks have a major impact on the behaviour of their users.

The activities of individuals or organisations consciously focused on attempts to change attitudes and behaviours of individuals, a smaller or larger group of people, are called an 'operation of influence'. The goal of operation of influence is to achieve impact on the target group audience, which consequently implies the power position of a side that leads the operation. The process could be simplified according to Dahl [35] suggestion by which, operation of influence is the ability of subject A to influence on subject $\mathrm{B}$ in order to influence on it in favour to subject B do something that otherwise would not do. One way of influencing the change of attitudes and forming the opinion of the target group, which is applied in the operations of influence, is the dissemination of information and data, messaging and knowledge exchange. A significant number of studies have worked out and pointed to the existence of a relationship between personality traits and knowledge sharing [36] [37] [38]

Research on the relationship between cyberspace and social psychology suggest that cyberspace offers numerous possibilities for "knowledge sharing" and "coercive operations designed to influence the target group change, compromising, destruction or theft of information access to information systems and networks" [39]. Research conducted by Deng [40] approved the existence of a relationship between the personality traits and behaviour on social networks based on the theory of the Big Five. Kosinski [41] suggests that there are psychologically significant links between the users' personalities, their preferences for the website and profile at the most famous social network Facebook. Upon contemporary technological achievements, the behaviour of users in cyberspace described as a new cyber dimension of personality, which Sartonen [42] describe as a cyber personality. The cyber personality is a "digital image" of a real personality and offers many opportunities to perform precise impact operations that can be directed to a specifically selected, specific target group, as it provides important information on the behaviour in cyberspace-when, in what way, through which devices and to which content the user accesses the Internet.

The theory of planned behaviour (TPB) explains that attitudes about behaviour play an important role in explaining human behaviour [43] and that attitudes towards specific behaviour are formed from prominent beliefs about this behaviour [44]. Also, TPB suggests that the impact on behaviour (and its change) can be made through changes in attitudes, subjective norms, and perceived behavioural (behavioural) control. According to Ajzen [30], the consequence of the exposure of subjects entity ${ }^{2}$ to new information and experiences that can lead to changes in their (for behavioural relevance) beliefs is to influence their intent, that is, to influence their behaviour. Unless there is a change in the beliefs of subjects, the likelihood of a change in their behaviour is also less likely. In addition, in the same work, Ajzen in favour of TPB proposes two-step intervention in order to influence the behaviour of the subjects. The first step is selection and programming of intervention or targeting, due which accent is on changing of the belief, since the author believes that failure to intervene can very often be associated with unchanged beliefs. The second step is the review and implementation of an intervention or deliberation. When the intervention project is established, it switches to the implementation phase, which involves the transition from intention to concrete action, that is, to change behaviour. Furthermore, Ajzen in the same research, based on contemporary knowledge in the field of social psychology, proposes that intervention ${ }^{3}$ has been focused on the change of beliefs and the reduction of discrepancies between intent and concrete behaviour [45].

Internet users, thanks to social networks and other Internet services (e-mail, e-news, websites, etc.), have the opportunity to be aware of significant reactions from the environment in real-time to the reactions of people who may have an impact on their behaviour.

\footnotetext{
${ }^{2}$ Entities can be individuals, potential users of some services, or clients who need to persuade them to buy a product, i.e. target groups of impact operations.

${ }^{3}$ An intervention may be considered an attempt to influence the behaviour of individuals or target groups.
} 
Therefore, by changing their status on social networks, by public commenting on certain phenomena and events, they can behave in accordance with the "expectations" for them, important persons, and in this way express intentions about future behaviour in real life. Behaviour in line with the "expectations" of significant individuals can be recognised on the Internet in the form of conforming with comments and attitudes of significant individuals, but it can also be in real life - by mimicking and supporting the views and activities of significant individuals.

Suggested conclusions in favour of contemporary projecting of SCM in a digital environment, recognise that:

- The behaviour of the Internet shortens the selection of the target group of psychological operations in cyberspace.

- The application of modern information technology shortens the time of selection of the target group for the PO.

- The means of mass communication have gained a new role in a modern society based on the influence of the media influence and political power, concentrated in certain social structures [46].

\section{CONCLUSIONS}

Strategic communication management in the contemporary world could have to be planned and activity. In the process, analyses of environment, stakeholders and objects are crucial and its demand a unique analytical approach. The environment of communication has various dimensions in the sense of a physical area, geographic characteristics, cultural, ethnic, etc. Cyberspace is present in almost all the above physical dimensions. In addition, strategic communication pillows (propaganda, public diplomacy and advocacy), as well as all other communication forms, are strongly dependable on Internet platforms and cyberspace activities. Supported by technology and globalisation of media and broadband Internet contexts in forms of different contexts, but especially as social networks, it is one of the strong tools in the shaping of public opinion, behaviour predictions, as well as attitude and mass motivation management. Especially, influence could be effective on readiness and motivation for defence and engagement in military operations, but also toward other issues, which could negatively influence on security and defence capabilities (national cohesion, trust in national leaders, unity, etc.). In the scope of that, planning and analysing of Internet communication should be considered as a part of strategic communication management, incorporated in defence and security strategic planning process.

\section{REFERENCES}

[1] K. Hallahan, D. R., Holtzhausen, B. Van Ruler, D. Verčič, and Sriramesh, K. "Defining strategic communication,"
International Journal of Strategic Communication, 2007, 1(1), pp.3-35 (p. 28).

[2] D. Holtzhausen, and A. Zerfass, "Strategic Communication: Opportunities and Challenges of the Research Area," The Routledge Handbook of Strategic Communication, Routledge, 2015, pp 3-17.

[3] K. Hallahan, D. R., Holtzhausen, B. Van Ruler, D. Verčič, and Sriramesh, K. "Defining strategic communication," International Journal of Strategic Communication, 2007, 1(1), pp.3-35 (p. 4).

[4] Oxford Bibliographies http://www.oxfordbibliographies.com/view/document/obo9780199756841/obo 9780199756841-0007.xml.

[5] M. Mitrovic, "Lobbying-Managing with Strategy Orientated Communication," Political behaviour: Cognition, Psychology, \& Behaviour eJournal, Vol. 11, No. 24, Apr 11, 2017.

[6] M. Mitrovic, "Startegic communication in function on national security," Vojno delo, No 1/2019, pp.41-54 (p. 42). (Мирослав Митровић, "Стратешка комуникација у функцији националне безбедности", Војно дело, 1/2019, cтp.41-54 (42))

[7] Report of the Defense Science Board Task Force on Managed Information Dissemination, Washington, D.C., October 2001. http://www.acq.osd.mil/dsb/reports/ADA396312.pdf)

[8] T. Helmus, P. Christopher, G.W. Russell, Enlisting Madison Avenue: The Marketing Approach to Earning Popular Support in Theaters of Operation, Santa Monica: MG-607-JFCOM, 2007, p. 171.

[9] P. Christopher, Getting Better at Strategic Communication, Calif.: RAND Corporation, 2011, p 5.

[10] P. Christopher, Strategic Communication Origins, Concepts, and Current Debates, Santa Barbara:Praeger, 2011, p. 4.

[11] K. Afifa, "Strategic communication in the 21st century: Understanding new evolving concept and its relevance for Pakistan," ISSRA Papers 2016, pp. 25-42 (p.27).

[12] U.S. Department of Defense, "QDR Execution Roadmap for Strategic Communication," September 2006. p. 3.

[13] Report of the Defense Science Board Task Force on Managed Information Dissemination, Washington, D.C., October 2001. As of July 1, 2011: http://www.acq.osd.mil/dsb/reports/ADA396312.pdf.

[14] P.J. Farwell, Persuasion, and power: the art of strategic communication, Washington, DC: Georgetown University Press, 2012

[15] W. S. Littlejohn, Theories of human communication, 2nd ed., Belmont, CA: Wadsworth, 1992.

[16] S. Langer, Mind: An essay on human feeling, Baltimore: Johns Hopkins University Press, 1967.

[17] M. Mitrovic, Startegic Lobbying, Kragujevac: Koraci, 2017, p.26. (M. Mitrović, Strateško lobiranje. Kragujevac: Koraci, 2017, str. 26.).

[18] M. Mitrovic, "Startegic communication in function on national security," Vojno delo, No 1/2019, pp.41-54 (p. 44). (Мирослав Митровић, "Стратешка комуникација у функцији националне безбедности", Војно дело, 1/2019, cтp.41-54 (44))

[19] M. Vracar, "Consideration of an adequate theoreticalepistemological approach in hybrid warfare phenomenon research Vojno delo, No.7/2017, pp.292-307. (М. Врачар, "Разматрање адекватног теоријско-епистемолошког приступа у истраживању феномена хибридног ратовања,” Војно дело 7/2017, стр. 292-307).

[20] M. Mitrovic, "Contribution to understunding of public opinioun-modeling, menagemnt and prediction of behaviour reactions,", Hybrid warfare-contemporary conflicts dilema, Belgrade:Strategic Research Institute, 2018, pp.195-213 (196-197). (М. Митровић, “Допринос разумевању јавног мнења - моделовање управљања и предвиђања реакција," Хибридно ратовање - дилема 
концепта савремних сукоба, Београд:Институт за стратегијска истраживања, стр. 195-213 (196-197). (http://www.isi.mod.gov.rs/mulhttp://www.isi.mod.gov.rs/ multimedia/dodaci/hibridno_ratovanje_tematski_zbornik_is i_2018_1545986523.pdf).

[21] D. Milosevic, "Hybrid conflict - postmodern war, a new face of the old phenomenon," Vojno delo No.1/2019, pp.172-183. (Д. Милошевић, "Хибридни сукобпостмодерни рат, ново лице старе појаве,” Војно дело 1/2019, стр:172-183)

[22] M. Libicki, What is Information Warfare, NDU, 1995 http://www.ndu.edu/inss/books/Books1990to1995/What_is _IW_Aug_95/a003ch03.html

[23] M. Miljkovic, "Hybrid Warfare in contemporary domensexamples of information operations," Hybrid warfarecontemporary conflicts dilema, Belgrade:Strategic Research Institute, 2018, pp. 169-180 (171-175). (М. Миљковић, "Хибридно ратовање у савременим доменима - пример информационих операција,", Хибридно ратовање дилема концепта савремних сукоба, Београд:Институт за стратегијска истраживања, стр. 169-180 (171-175) (http://www.isi.mod.gov.rs/mulhttp://www.isi.mod.gov.rs/ multimedia/dodaci/hibridno_ratovanje_tematski_zbornik_is i_2018_1545986523.pdf)

[24] D. Vuletic, "The use of cyberspace in the context of hybrid warfare,", Vojno delo No 7/2017, pp. 308-325 (312). (D Vuletić, "Upotreba sajber prostora u kontekstu hibridnog ratovanja," Vojno delo, 7/2017, str.308-325 (312)).

[25] M.Mitrovic and M. Miljkovic, "Hybrid genesis of information operations in cyberspace," TEME, XLII, No. 4, October-Decembre 2018, pp. 1359-1372.

[26] Doctrine for Joint Psychological Operations, Joint Publication 3-53, Washington D.C: Joint Chiefs of Staff, 5 September 2003.

[27] A. Bandura, Social cognitive theory, Stanford University, 1989

https://www.uky.edu/ eushe2/Bandura/Bandura1989ACD pdf

[28] K. Lewin, Psychological constructs and sources of brain cognitive activity, https://arxiv.org/ftp/arxiv/papers/1711/1711.01767.pdf

[29] "Social media as a tool of hybrid warfare", NATO Strategic Communications Centre of Excellence May 2016, p.6. https://public_report_social_media_hybrid_warfare_22.07. 2016.pdf.

[30] I. Ajzen, Summary of Theory of Planned Behaviour. Abstract. Retrieved May 8, 2017 , http://www.valuebasedmanagement.net/methods_ajzen_the ory_planned_behaviour.html.

[31] W, Hansen, Influence: theory and practice, Master of Science in defense analysis, Naval postgraduate school, Monterey California, 2013.

[32] A. Pratkanis, "Winning Hearts and Minds: A Social Influence Analysis," in Information Strategy and Warfare, ed. John Arquilla and Douglas A. Borer, New York: Routledge, 2007.

[33] H. Kelman, "Compliance, identification, and internalization: Three processes of attitude change," Journal of Conflict Resolution 1, 1958, pp.51-60.
[34] Statista 2018, https://hostingfacts.com/internet-facts-stats/.

[35] P. Dahl, "The Concept of Power," Behavioural Science, 2:3, July 1957.

[36] A. Beldad and M. Kusumadewi, "Here's my location, for your information: The impact of trust, benefits, and social influence on location sharing application use among Indonesian university students," Computers in Human Behaviour No.49, August 2015.

[37] A. Gupta and A. Dhami, "Measuring the impact of security, trust and privacy in information sharing: A study on social networking sites," Journal of Direct, Data and Digital Marketing Practice, September 2015, Volume 17, Issue 1, pp. 43-53.

[38] J. Liu, P. Rau, and N. Wendler, "Trust and online information-sharing in close relationships: A cross-cultural perspective," Behaviour and Information Technology 34(4):1-12, December 2014

[39] N. Pissanidis, H. Rõigas and M.Veenendaal, "Influence Cyber Operations: The Use of Cyberattacks in Support of Influence Operations," 8th International Conference on Cyber Conflict Cyber Power, NATO CCD COE Publications, Tallinn 2016.

[40] Z. Deng and S. Liu, "Understanding consumer health information-seeking behaviour from the perspective of the risk perception attitude framework and social support in mobile social media websites," International Journal of Medical Informatics, Volume 105, September 2017, pp. 98109.

[41] M. Kosinski, Y. Bachrach, P. Kohli, D. Stillwell, and Thore Graepel, "Manifestations of user personality in website choice and behaviour on online social networks," Machine Learning, June 2014, Volume 95, Issue 3, pp 357-380.

[42] M. Sartonen, A-M. Huhtinen and M. L. Rhizomatic, "Target Audiences of the Cyber Domain," Journal of Information Warfare Volume 15, Issue 4 Fall 2016, pp.114

[43] K. Olivova, "Intention to buy organic food among consumers in the Czech Republic," Master thesis, University of Agder, Czech Republic, 2011.

[44] I. Ajzen, "From Intentions to Actions: A Theory of Planned Behaviour," In Kuhl J., Beckmann J. (eds) Action Control. SSSP Springer Series in Social Psychology. Springer, Berlin, Heidelberg, 1985, pp.11-39.

[45] G. Ratkajec, G., D. Hundric, J. Mihic, "Willingness to change behaviour - from individual to family paradigm,"( G. Ratkajec, G., D. Hundrić, J. Mihić" Spremnost na promjenu ponašanja - od individualne prema obiteljskoj paradigmi,") Kriminologija i socijalna integracija Vol. 24 Br.1. 2016

[46] M. Cabarkapa, "The Role of Media and Psychological Propaganda in Contemporary War, with a Special Focus on Armed Conflicts in the Former Yugoslavia," Proceedings of the Faculty of Philosophy, XXXVII/2007, K.Mitrovica, 2008. (М. Чабаркапа, “Улога медијске и психолошке пропаганде у савременом рату са посебним освртом на оружане сукобе у бившој Југославији,” Зборник радова филозофског факултета XXXVII/2007, К. Митровица, 2008.) 